\title{
Pulmonary Inflammatory Myofibroblastic Tumor in Children: A Case Report and Brief Review of Literature
}

\author{
Federica Camela ${ }^{1}$, Marcella Gallucci ${ }^{1}$, Emanuela di Palmo ${ }^{1}$, Salvatore Cazzato ${ }^{2}$, \\ Mario Lima ${ }^{3}$, Giampaolo Ricci ${ }^{1 *}$ and Andrea Pession ${ }^{1}$
}

\begin{abstract}
'Department of Pediatrics, S. Orsola-Malpighi Hospital, University of Bologna, Bologna, Italy, ${ }^{2}$ Department of Mother and Child Health, Salesi Children's Hospital, Ancona, Italy, ${ }^{3}$ Department of Pediatric Surgery, S. Orsola-Malpighi Hospital, University of Bologna, Bologna, Italy
\end{abstract}

\section{OPEN ACCESS}

Edited by:

Elif Dagli,

Emeritus Marmara University,

Turkey

Reviewed by:

Andrew A. Colin,

University of Miami,

United States

Yusei Ohshima,

University of Fukui, Japan

*Correspondence:

Giampaolo Ricci

giampaolo.ricci@unibo.it

Specialty section:

This article was submitted to

Pediatric Pulmonology,

a section of the journal

Frontiers in Pediatrics

Received: 06 September 2017 Accepted: 07 February 2018 Published: 27 February 2018

Citation:

Camela F, Gallucci M, di Palmo E, Cazzato S, Lima M, Ricci G and Pession A (2018) Pulmonary Inflammatory Myofibroblastic

Tumor in Children: A Case Report and Brief Review of Literature.

Front. Pediatr. 6:35. doi: 10.3389/fped.2018.00035
The inflammatory myofibroblastic tumor (IMT) is a rare lesion of unclear etiology and variable clinical course, consisting of a proliferation of fibroblasts and myofibroblasts, mixed with inflammatory cells. Synonyms of IMT are inflammatory pseudotumor and plasma cell granuloma reflecting the alleged inflammatory nature attributed to this lesion, even though this heterogeneity in the disease denomination is probably involved in a dispersion of the literature data. Among primary pulmonary neoplasms, it represents the most frequent endobronchial tumor of childhood and beyond the lung it has been described mainly in the bladder, mediastinum and mesentery. Despite having a tendency for local recurrence, the risk of distant metastasis is low. Clinical presentation depends on localization therefore lung peripheral lesions are often asymptomatic resulting in a delayed diagnosis. Radiological findings can suggest the diagnosis that must be confirmed by histopathology assessment. The tumor has been characterized by the application of immunohistochemical techniques, molecular biology and cytogenetics, which are very precious for the diagnosis. The therapeutic approach consists in the complete surgical excision of the lesion that normally ensures excellent survival. Due to the potential risk of recurrence, close clinical trial is indicated. To date only 24 cases of pulmonary IMT have been described, although the prevalence is probably higher. We present a case report of a 3-year-old girl with pulmonary IMT and a brief review of known literature cases in order to highlight the most common clinical presentations, the most useful diagnostic tools and therapeutic approach.

Keywords: inflammatory myofibroblastic tumor, inflammatory pseudotumor, high-resolution computer tomography, histopathology assessment, anaplastic lymphoma kinase rearrangement

\section{INTRODUCTION}

Primary pulmonary neoplasms in pediatric patients are uncommon diseases. Among these disorders, the inflammatory myofibroblastic tumor (IMT) represents $20 \%$ of all primary lung tumors and more of $50 \%$ of all benign masses $(1,2)$.

The World Health Organization (WHO) defines IMT as "a lesion composed of a proliferation of myofibroblastic spindle and stellate cells with abundant eosinophilic cytoplasm mixed with infiltrative plasma, inflammatory cells, lymphocytes and eosinophils" $(3,4)$.

Abbreviations: IMT, inflammatory myofibroblastic tumor; IPT, inflammatory pseudotumor; HRCT, high-resolution computer tomography; ALK1, anaplastic lymphoma kinase 1; MRI, magnetic resonance imaging; CXR, chest X-ray. 
The same entity was called in the past with other names; the most recognized ones were inflammatory pseudotumor (IPT), plasma cell granuloma, and postinflammatory tumor.

Inflammatory pseudotumor was considered as a reaction to an inflammatory insult $(1,5)$. It involve more often liver and biliary tract $(31.8 \%$ of cases), head and neck (20.6\%), lung (18.2\%), abdomen (15.5\%), and urogenitary system (7.4\%) (6). Although it was considered in the past a non-neoplastic reactive inflammation, in 2006 WHO defined it an intermediary lesion with clinical recurrence and malignant potential (4).

These generic appellations reflect the alleged inflammatory and non-neoplastic nature attributed to these lesions, even though confusion regarding the distinction of these tumors from other entities such as the "inflammatory fibrosarcoma"

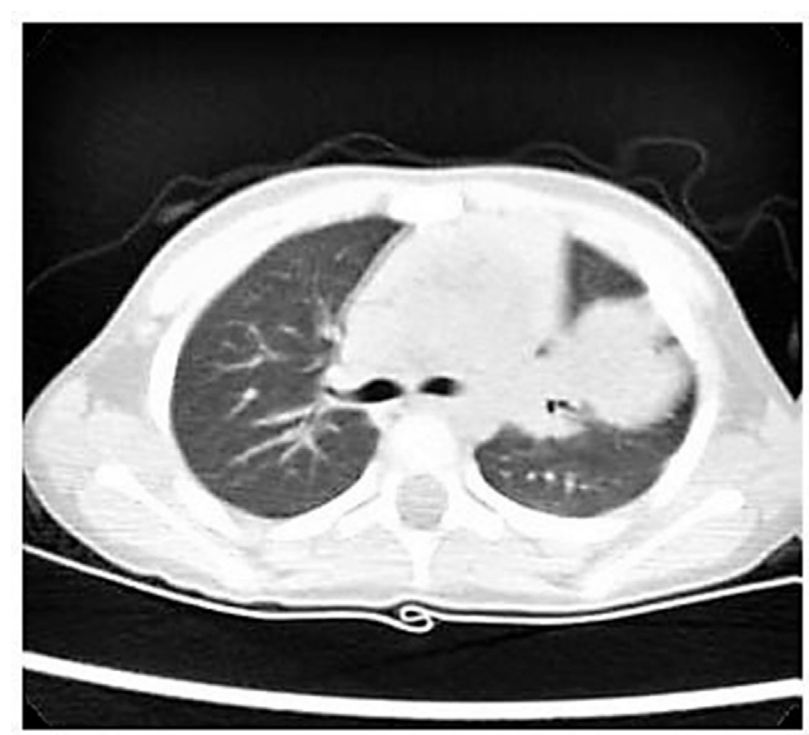

FIGURE 1 | High-resolution computer tomography imaging showing a large lung lesion in the left parahilar side.

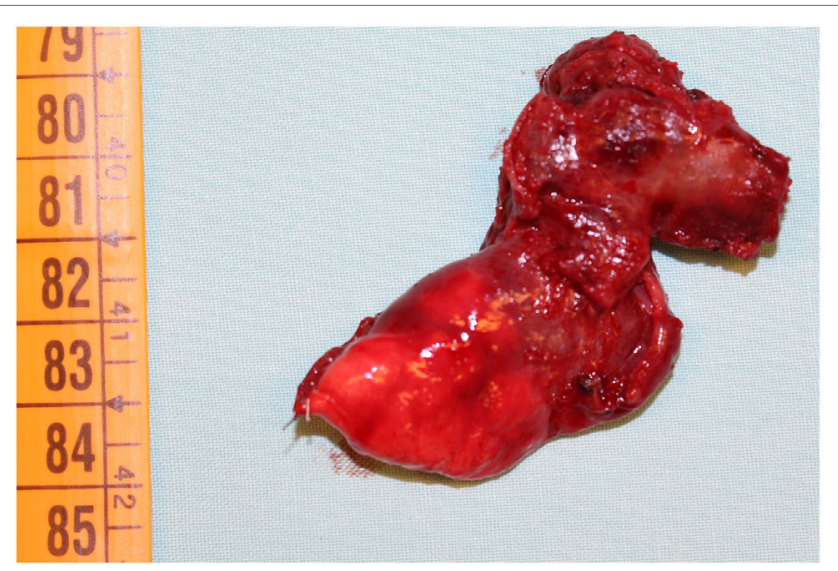

FIGURE 2 | Surgical sample of lingula inflammatory myofibroblastic tumor in 3-year-old child. (considered indistinguishable from the IMT), still remains $(5,7)$. This ambiguity in the denomination may be a factor favoring the dispersion of the literature data and then an underreporting.

\section{CASE REPORT}

We describe the case of a 3-year-old girl, born at 33 weeks of gestational age with a good neonatal adaptation. Starting from the age of 18 months, she presented with recurrent infections of lower and upper airways, which were often treated with antibiotic therapy. She came to our attention from another medical center.

In the previous 2 months, the child showed intermittent fever, loss of appetite and dry cough.

The chest X-ray (CXR) showed a rounded $2 \mathrm{~cm}$ diameter opacity in the left parahilar side, therefore she consecutively was treated with oral therapy with penicillin, cephalosporin of third generation and macrolide. Despite therapy, at first evaluation to our center the child was still having evening fever and poor general condition.

Chest auscultation revealed reduced air entry and fine crackles on the left hemithorax. The laboratory tests showed a stable increase of inflammatory markers: C-reactive protein $9.5 \mathrm{mg} / \mathrm{dL}$ (normal range $<0.08 \mathrm{mg} / \mathrm{dl}$ ), erythrocyte sedimentation rate $102 \mathrm{~mm}$, leukocytes $11 \times 10^{6} / \mathrm{L}$ (59\% neutrophils, 32\% lymphocytes, $8 \%$ monocytes, $0.4 \%$ eosinophils, and $0.7 \%$ basophils), hemoglobin $12 \mathrm{mg} / \mathrm{dL}$, and platelet $809 \times 10^{3} / \mu \mathrm{L}$.

The nasal-pharyngeal samples culture and blood culture were both negative, including research for multidrug-resistant staphylococcus.

Nevertheless, we started with empiric therapy with Piperacillin/ Tazobactam and Linezolid. A few days later, because of persistent fever with altered laboratory and radiological findings, the child underwent a chest high-resolution computer tomography (HRCT) that showed a large lung lesion with thickened wall and fluid content at the lingula level (Figure 1). The mass diameter was about $35 \mathrm{~mm}$. Suspecting a necrotizing pneumonia, surgical removal of the lesion was performed by atypical resection. The subsequent histological assessment showed an IMT positive for actin, anaplastic lymphoma kinase 1 (ALK1), and desmin (Figure 2). Subsequently, to achieve a complete removal of the lesion margins, the left upper lobectomy by thoracotomy was necessary.

The postoperative course was uncomplicated. After surgery, the clinical picture of the child gradually improved with remission of fever. At 6, 12, and 18 months of follow-up, she presented good clinical conditions and radiological evidence of atelectasis to the left lower lobe, compatible with recent surgery.

\section{DISCUSSION}

Although the spectrum of primary lung tumors in the childhood is the same as in adults, the lesions have different prevalence (8). IMT shows a high incidence in children and young people, representing $50 \%$ of primary benign lung tumor in infancy $(1,2)$.

Pulmonary IMT typically presents itself as a parenchymal nodule and occasionally as an endobronchial lesion (2). It has a tendency to grow slowly but can invade local structures (1). 
The clinical picture depends primarily on the location of the tumor but most patients have a few respiratory symptoms so the diagnosis may be delayed.

Children with IMT may exhibit symptoms of chronic inflammation as a low-grade fever, weight loss, anemia, thrombocytosis, polyclonal hypergammaglobulinemia, and elevated sedimentation rate. Several cases are asymptomatic and are detected only incidentally on imaging studies.

Among patients with endobronchial lesions, symptoms of bronchial irritation such as cough and hemoptysis may be accompanied by chest pain (3).

In the current case, the previous clinical history, CXR and the presence of intermittent fever suggested at first an infectious disease. Nevertheless, the failure to respond to broad-spectrum antibiotics brought us to investigate the presence of a noninfectious lesion. The chest HRCT was decisive even though the diagnosis could not have been possible without histological assessment.

According to literature data, there are only 24 published cases of pediatric pulmonary IMT (the age thereof ranges from 3 to 13 years), even though the real incidence is presumed to be higher. Peripheral lung lesions appear to be more frequent than central and endobronchial tumors that may be present about in $10 \%$ of the cases resulting in bronchial obstruction and atelectasis (2).

Among the 24 described cases, the tumor grew in trachea in 5 patients (3 in carina; $20 \%$ of total) and was peripheral in 19 cases it ( $80 \%$ of cases). These peripheral masses were located in 11 cases $(46 \%)$ in the left lobes and in 8 cases $(33 \%)$ in the right lobes. At the onset, the mass was average on $4.5 \mathrm{~cm}$ of the diameter $(1.4-12 \mathrm{~cm})$; four subjects $(17 \%)$ presented metastasis and secondary masses were discovered in one case after 11 months of follow-up. At the time of diagnosis, the IMT involved adjacent structures in five cases (21\%): chest wall, main bronchus, mediastinum, hilum, or pulmonary artery (Table 1). In some of these cases, the patients came to clinicians' attention with symptoms related to the local effects of the mass such as stridor or a history of wheezing (5).

Inflammatory myofibroblastic tumor can be sometimes detected as incidental finding on a routine CXR (27). In all cases, at presentation patients had fever, respiratory distress, arthralgia, clubbing, night sweat, vomiting, and hemoptysis. At the onset, fever and cough were the commonest symptoms (Table 2).

Data collected from the literature show that central IMT are recognized earlier, probably due to the resulting symptoms (acute obstruction of the trachea, carena, or main bronchus). On the contrary, peripheral parenchymal tumors cause more misleading and nonspecific symptoms leading to delayed diagnosis.

Including our patient, in nine cases the children presented with variable degree of anemia. They also showed laboratory findings of chronic inflammation such as leukocytosis, hypergammaglobulinemia, elevated platelet count, increase of erythrocyte sedimentation rate, and C-reactive protein (12, 14, $15,17,18,24)$.

The anatomopathological differential diagnosis is wide and must be conducted on the clinical picture, morphological alterations, and the immune phenotype of spindle cells.
Differential diagnosis must include foreign body aspiration, infectious disease (Aspergillum and Mycobacterium) but also necrotizing pneumonia and spindle cell neoplasms (1).

The histological assessment is essential to rule out pseudolymphomas, malignant lymphomas, lymphoid hyperplasia and sarcomas such as leiomyosarcoma, fibrosarcoma, rhabdomyosarcoma, myxoid sarcoma, malignant fibrous histiocytoma, and gastrointestinal stromal tumor $(12,14,15,17,18,24,27,28)$.

Chest X-ray usually reveal a peripheral lesion or nodule of variable size (diameter usually ranges from 1.2 to $15 \mathrm{~cm}$,) more often localized in the lower lobes (29). Rarely, patients may have multiple lesions (30).

Among the literature cases, 16/24 subjects underwent HRCT often showing solid masses with homogeneous or heterogeneous enhancement (Table 1). These lesions appear as single, well-defined, lobulated mass and frequently contain punctate calcifications that mimics malignant tumors (20).

Positron emission tomography/computed tomography is highly sensitive but has low specificity for IMT. It could be useful to evaluate the response to treatment in patients not eligible for surgery (31).

Bronchoscopy is usually performed when there exists a suspect of endoluminal lesion. It is a useful diagnostic and therapeutic tool since it has both a function of removing tumoral obstruction and providing biopsy samples $(13,19)$.

Moreover, due to local recurrence risk, bronchoscopy may have a potential role in the follow-up even though future evidences are necessary to define the timing of endoscopic revaluation.

Among all pediatric known cases, only three subjects underwent magnetic resonance imaging (MRI): in two cases the chest MRI confirmed the HRCT findings and MRI was performed only in one case in place of $\operatorname{HRCT}(19,20)$.

Takayama et al. suggest that radiological presentation and contrast-enhancement in pediatric IMT are variable and nonspecific. Moreover, calcifications within the tumor are present more often in children than in adults (these were reported in seven children; $29 \%$ of cases) (20).

In association with lesions, there could be pneumothorax, pleural effusion, atelectasis, and rarely cavitations and lymphadenopathies (Table 1).

Molecular rearrangements on chromosome 2p23 were detected in several cases of IMTs (in about $34-56 \%$ of both pulmonary and extrapulmonary IMTs). This locus is the site of human $A L K$ gene, which codes for a tyrosine kinase receptor called ALK. ALK rearrangements are identified by immunohistochemical analysis (fluorescence in situ hybridization) using monoclonal ALK-1 antibody and seems to be highly specific for these lesions, even though it does not seem to be a sensitive marker in children $(32,33)$. Furthermore, ALK-positivity does not seems to be related to recurrence $(1,5,33,34)$.

Abnormal karyotypes of tumor cells, like aneuploidy, were found in $16 \%$ of cases $(32,33)$. RET gene rearrangement, EML4$A L K$ inversion, and fusions of other kinases gene have also been implicated (35).

Alaggio et al. in a recent report found that cytologic atypia and positive ALK status are more frequent in aggressive tumors, whereas metastatic tumors are negative for ALK. 
TABLE 1 | Review of 25 known cases of pediatric pulmonary IMT, including our case: diagnostic tools, histological assessment, and immune-histochemical analysis of lung bioptic samples.

\begin{tabular}{|c|c|c|c|c|}
\hline & Patients & Diagnostic tools & Histological assessment & $\begin{array}{l}\text { Immuno-histochemical } \\
\text { analysis }\end{array}$ \\
\hline $\begin{array}{l}\text { El-Desoky } \\
\text { et al. (9) }\end{array}$ & $F, 9 y$ & HRCT: mass in left main bronchus & Compatible with IMTa & n.d. \\
\hline $\begin{array}{l}\text { Johnson } \\
\text { et al. (10) }\end{array}$ & M, 7 y & CXR: solitary right lung mass & $\begin{array}{l}\text { Compact spindle cells mixed with abundant plasma cells } \\
\text { and lymphocytes. Extensive collagenous deposition with } \\
\text { metaplastic bone and numerous calcific deposits. } \\
\text { Metastatic IMT involving the entire visceral and parietal } \\
\text { pleural surfaces }\end{array}$ & Positive for vimentin \\
\hline $\begin{array}{l}\text { Hammas } \\
\text { et al. (11) }\end{array}$ & M, 3 y & HRCT: left lower lobe mass & $\begin{array}{l}\text { Proliferation of regular spindle cells arrayed in fascicles, } \\
\text { mixed with lymphocytes, plasma cells and eosinophils }\end{array}$ & $\begin{array}{l}\text { Positive for ALK1, SMA, and } \\
\mathrm{H} \text {-caldesmon }\end{array}$ \\
\hline \multirow[t]{3}{*}{$\begin{array}{l}\text { Prahbu } \\
\text { et al. (12) }\end{array}$} & $F, 4.5$ y & $\begin{array}{l}\text { CXR and HRCT: large circumscribed } \\
\text { mass in the left hemithorax abutting the } \\
\text { left anterolateral chest wall; calcification } \\
\text { and areas of necrosis within }\end{array}$ & Not available data & n.d. \\
\hline & $F, 6$ y & $\begin{array}{l}\text { CXR and HRCT: large left upper lobe } \\
\text { mass with areas of necrosis and } \\
\text { calcification within }\end{array}$ & $\begin{array}{l}\text { Spindle cell proliferation with focally hyalinized, collagenized } \\
\text { stroma and dense chronic inflammation with several plasma } \\
\text { cells }\end{array}$ & Positive for vimentin and SMA \\
\hline & $\mathrm{F}, 8$ y & $\begin{array}{l}\text { CXR and HRCT: mass in left hemithorax } \\
\text { abutting the left pulmonary artery; similar } \\
\text { left paravertebral lesion }\end{array}$ & Compatible with IMTª & Not available data \\
\hline \multirow[t]{3}{*}{$\begin{array}{l}\text { Brodlie } \\
\text { et al. (13) }\end{array}$} & $F, 9 y$ & $\begin{array}{l}\text { CXR: well-circumscribed solitary right } \\
\text { apical mass }\end{array}$ & Spindle cells with an inflammatory infiltrate & Not available data \\
\hline & $F, 15$ y & $\begin{array}{l}\text { HRCT: well-circumscribed left main } \\
\text { bronchus mass }\end{array}$ & Compatible with IMTa & Positive per ALK \\
\hline & $F, 11 y$ & Bronchoscopy & Compatible with IMTa & Not available data \\
\hline $\begin{array}{l}\text { Sacco } \\
\text { et al. (14) }\end{array}$ & $\mathrm{F}, 6$ y & $\begin{array}{l}\text { HRCT: round paratracheal mass in the } \\
\text { right middle portion of the mediastinum }\end{array}$ & $\begin{array}{l}\text { Fusiform, fibroblast-like cells and spindle cells surrounded by } \\
\text { a collagenous stroma, growing in interlacing fascicles with } \\
\text { prominent storiform pattern }\end{array}$ & $\begin{array}{l}\text { Positivity for vimentin, SMA, } \\
\text { and clusterin }\end{array}$ \\
\hline $\begin{array}{l}\text { Ochs } \\
\text { et al. (15) }\end{array}$ & $\mathrm{F}, 5 \mathrm{y}$ & $\begin{array}{l}\text { HRCT: mass in left main bronchus with } \\
\text { bronchial obstruction; atelectasis of the } \\
\text { left haemitorax }\end{array}$ & $\begin{array}{l}\text { Intrabronchial IPT (fibrohistiocytoma type): benign spindle } \\
\text { cells with submucosal tissue with a palisading pattern (arrow) } \\
\text { and admixed leukocytes }\end{array}$ & Not available data \\
\hline $\begin{array}{l}\text { Fernández del } \\
\text { Castillo Ascanio } \\
\text { et al. (16) }\end{array}$ & $F, 5$ y & $\begin{array}{l}\text { HRCT: left lung mass extending to } \\
\text { anterolateral mediastinum and abutting } \\
\text { the left pulmonary artery and left main } \\
\text { bronchus; } 1 \text { contralateral lung lesion and } \\
7 \text { brain masses }\end{array}$ & Compatible with IMTa & Not available data \\
\hline \multirow[t]{2}{*}{$\begin{array}{l}\text { Lindemans } \\
\text { et al. (17) }\end{array}$} & $\mathrm{M}, 6 \mathrm{~m}$ & HRCT: solid left upper lobe mass & $\begin{array}{l}\text { Highly proliferative myofibroblastic spindle cells whit an } \\
\text { infiltrate of mononuclear cells, macrophage foam cells and } \\
\text { sporadic necrotic debris }\end{array}$ & Not available data \\
\hline & $\mathrm{F}, 6 \mathrm{y}$ & $\begin{array}{l}\text { Ultrasound: solid right lower lobe mass; } \\
\text { central calcification }\end{array}$ & Solid area of proliferating fibroblast with collagen and fibrosis & Not available data \\
\hline $\begin{array}{l}\text { Lizarbe } \\
\text { et al. (18) }\end{array}$ & $\begin{array}{l}\text { M, } 8 \text { y } \\
\text { and } 10 \\
\quad m\end{array}$ & $\begin{array}{l}\text { HRCT: tracheal mass abutting the left } \\
\text { main bronchus; left lung collapsed }\end{array}$ & $\begin{array}{l}\text { Mixoid areas with abundant vascularization, fibroblast cells, } \\
\text { epithelioid cells, and histiocytes mixed with inflammatory } \\
\text { cells }\end{array}$ & $\begin{array}{l}\text { Positive per vimentina, } \\
\text { desmina, SMA, CK AE1-AE3, } \\
\text { ALK, protein S-100, and HHV8 }\end{array}$ \\
\hline $\begin{array}{l}\text { Breen } \\
\text { et al. (19) }\end{array}$ & $\mathrm{F}, 11 \mathrm{y}$ & $\begin{array}{l}\text { MR: endobronchial mass located in the } \\
\text { left main stem bronchus }\end{array}$ & Compatible with IMTa & Not available data \\
\hline \multirow[t]{2}{*}{$\begin{array}{l}\text { Takayama } \\
\text { et al. (20) }\end{array}$} & $M, 4$ y & $\begin{array}{l}\text { HRCT and MR: well-circumscribed right } \\
\text { upper lobe mass }\end{array}$ & $\begin{array}{l}\text { Homogeneously whitish mass with spindled myofibroblasts, } \\
\text { chronic inflammatory infiltrate, and lymphoid aggregates }\end{array}$ & Positive for SMA \\
\hline & $\mathrm{F}, 7 \mathrm{y}$ & $\begin{array}{l}\text { HRCT and MR: well-circumscribed round } \\
\text { mass in the left lower lobe }\end{array}$ & $\begin{array}{l}\text { Homogeneously red tissue, composed of spindled } \\
\text { myofibroblasts with chronic inflammatory infiltrate and } \\
\text { lymphoid aggregates }\end{array}$ & Positive for SMA \\
\hline $\begin{array}{l}\text { Venizelos } \\
\text { et al. }(21)\end{array}$ & $M, 13$ y & HRCT: mass at bifurcation of the trachea & $\begin{array}{l}\text { Spindle shaped cells with ovoid or round-shaped nuclei, } \\
\text { sparse chromatin and eosinophilic cytoplasm. Nuclear } \\
\text { pleomorphism, minimal and rare mitotic figures }\end{array}$ & $\begin{array}{l}\text { Positive for vimentin, ALK and } \\
\text { CD68. A few cells exhibited } \\
\text { reactivity for SMA and muscle } \\
\text { specific actin }\end{array}$ \\
\hline
\end{tabular}


TABLE 1 | Continued

\begin{tabular}{|c|c|c|c|c|}
\hline & Patients & Diagnostic tools & Histological assessment & $\begin{array}{l}\text { Immuno-histochemical } \\
\text { analysis }\end{array}$ \\
\hline $\begin{array}{l}\text { Sivanandan } \\
\text { et al. (22) }\end{array}$ & $\mathrm{F}, 9 \mathrm{y}$ & Bronchoscopy & $\begin{array}{l}\text { Squamous lining epithelium and a spindle cell lesion in the } \\
\text { sub-epithelial region }\end{array}$ & Positivity for SMA, vimentin \\
\hline $\begin{array}{l}\text { Hoseok } \\
\text { et al. (23) }\end{array}$ & $M, 4 y$ & Bronchoscopy & $\begin{array}{l}\text { Proliferation of spindle-shaped fibroblasts and myofibroblasts } \\
\text { arrayed in fascicles with some storiform architecture. }\end{array}$ & Positive for SMA and vimentin \\
\hline $\begin{array}{l}\text { Pichler } \\
\text { et al. (24) }\end{array}$ & $F, 12$ y & $\begin{array}{l}\text { CXR and HRCT: large and solid } \\
\text { homogeneous lesion with contrast } \\
\text { enhancement }\end{array}$ & $\begin{array}{l}\text { Solid and well encapsulate, different level of fibrosis and } \\
\text { inflammation of normal plasma cells as well as some } \\
\text { macrophages, lymphocytes, and eosinophils }\end{array}$ & Not available data \\
\hline $\begin{array}{l}\text { Chan } \\
\text { et al. (25) }\end{array}$ & $\mathrm{F}, 7 \mathrm{y}$ & $\begin{array}{l}\text { HRCT: large mass enveloping the right } \\
\text { main bronchus }\end{array}$ & $\begin{array}{l}\text { Fibrous tissue with areas of necrosis, extensive lymphocytic } \\
\text { infiltration, and plasma cells }\end{array}$ & Not available data \\
\hline $\begin{array}{l}\text { Prasad } \\
\text { et al. (26) }\end{array}$ & $\mathrm{M}, 12 \mathrm{y}$ & $\begin{array}{l}\text { CXR: round homogenous left-paracardiac } \\
\text { mass }\end{array}$ & Compatible with IMTa & Not available data \\
\hline $\begin{array}{l}\text { Current case, } \\
2017\end{array}$ & $\mathrm{~F}, 3 \mathrm{y}$ & $\begin{array}{l}\text { HRCT: large lung lesion with thickened } \\
\text { wall and fluid content at the lingula level }\end{array}$ & Spindle cell proliferation with inflammatory infiltrate & $\begin{array}{l}\text { Positive for actin, ALK1, and } \\
\text { desmin }\end{array}$ \\
\hline
\end{tabular}

y, years; $m$, months; w, weeks; d, days; $h$, hours; n.d., not done, immuno-histochemical analysis not performed; CXR, chest X-ray; HRCT, high-resolution computer tomography; MR, magnetic resonance; ALK, anaplastic lymphoma kinase; SMA, alfa-smooth muscle actin; CK, cytokeratins (AE 1-3).

aHistological features not specified by the authors.

TABLE 2 | Frequency of symptoms in pediatric pulmonary IMT, including our case.

\begin{tabular}{lc}
\hline Symptoms at presentation & Symptoms rate $^{\mathbf{a}}$ \\
\hline Cough & $12(48 \%)$ \\
Fever & $11(44 \%)$ \\
Respiratory distress & $10(40)$ \\
Anemia & $9(36 \%)$ \\
Weight loss & $5(20 \%)$ \\
Stridor & $3(12 \%)$ \\
Chest pain & $2(8 \%)$ \\
Recurrent respiratory infections & $2(8 \%)$ \\
Arthralgia & $2(8 \%)$ \\
Clubbing & $2(8 \%)$ \\
Sweat & $2(8 \%)$ \\
Wheezing & $2(8 \%)$ \\
Exertional dyspnea & $1(4 \%)$ \\
Seizure & $1(4 \%)$ \\
Hemoptysis & $1(4 \%)$ \\
Vomiting & $1(4 \%)$ \\
Asymptomatic & $1(4 \%)$
\end{tabular}

The table lists the cases of literature except one in which the author did not specify symptoms related to right-side pneumonia (20). One asymptomatic case is reported in a child with incidental diagnosis made by CXR (10).

a Number of patients; the parentheses indicate the percentage of symptoms.

Among previous pediatric cases described, positivity to vimentin (29\%), alpha-smooth muscle actin (alpha-SMA) (21.6\%), ALK (16.6\%), and other markers like desmin, cytokeratins (AE 1-3), CD34, protein S-100, and HHV8 was reported (32-34).

Treatment is primarily a complete but conservative surgical excision (3). This approach is necessary to prevent recurrence $(1,28)$. An appropriate histologic assessment should be obtained before the surgery (needle biopsy by bronchoscopy), in order to avoid an unnecessarily procedure (28).

Among all cases, 15 patients underwent open lung surgery, 2 resections by laser, 1 surgery by thoracoscopy, and 1 child was treated with bronchoscopic excision. In one case treated with open surgery, coexistent cerebral masses were detected and they required chemotherapy (16).

The most appropriate surgical approach (such as use of the wedge resection, lobectomy, and pneumonectomy) depends on the specific dimension and tumor localization, its relationship with the surrounding structures and the surgical equipment experience (36).

Partial resection may be necessary in cases where it is not possible to remove the lesion because of invasion of the vital structures. Among these cases, chemotherapy may be an alternative option for patients who have microscopic or macroscopic residual disease, although the results are controversial (32).

Described therapy for expanded masses were vinblastine plus methotrexate (14).

Although systemic steroids showed some beneficial effects in IMT, Sacco et al. found that the use of Prednisone may favorite the progression of lesion probably due to immunosuppression, therefore the authors suggest caution in the use of this drug in IMT (15).

In two cases without metastasis or local invasion, chemotherapy (methotrexate or cyclophosphamide associated with prednisone) was started as primary treatment (13).

In others two cases, the clinicians decided to undertake a therapy with only corticosteroids without evidence of recurrence at follow-up (15). Another case was treated only with COX-2 inhibitor after evidence of unresectable mass, with complete resolution at 8 months of follow-up (25).

Among all patients, only three children had tumor recurrence $(10,12,17)$.

Although recurrence is described as a rare phenomenon (14\% of pulmonary IMT) a close follow-up should be made for the early recognition of tumor relapse. In addition, the local invasion at diagnosis was highly correlated with local relapse $(9,11,37)$.

In our case, we decided to perform a complete surgical excision of the lesion followed by left upper lobectomy; nevertheless, to date we do not know the rate of survival after surgery versus 
others managements. The most recent evidence in young adult (mean age 33 years) suggests a 5- and 10-year disease-free survival of $89 \%$ after complete resection $(23,26,37)$.

\section{TAKE HOME MESSAGE}

- Pulmonary IMT is an uncommon disease but with significant morbidity among the pediatric population.

- Children may show non-specific and variable symptoms therefore they often underwent several antibiotic treatments before diagnosis.

- Radiological techniques are useful in suspected lesions but the diagnosis must be confirmed by histopathological assessment.

- Surgical complete resection is the treatment of choice.

- Because of the potential malignant behavior of these tumors, a close follow-up should be done to recognize the recurrences earlier.

- Due to the rarity of the disease among the pediatric population, it may be useful for the future to include all known

\section{REFERENCES}

1. Weldon CB, Shamberger RC. Pediatric pulmonary tumors: primary and metastatic. Semin Pediatr Surg (2008) 17:17-29. doi:10.1053/j.sempedsurg.2007. 10.004

2. Al-Qahtani AR, Di Lorenzo M, Yazbeck S. Endobronchial tumors in children: institutional experience and literature review. J Pediatr Surg (2003) 38:733-6. doi:10.1016/jpsu.2003.50195

3. Dishop MK, Kuruvilla S. Primary and metastatic lung tumors in the pediatric population. A review and 25-year experience at a large children's hospital. Arch Pathol Lab Med (2008) 132:1079-103. doi:10.1043/1543-2165(2008)132[107 9:PAMLTI]2.0.CO;2

4. Fletcher $\mathrm{CD}$. The evolving classification of soft tissue tumours: an update based on the new WHO classification. Histopathology (2006) 48:3-12. doi:10.1111/j.1365-2559.2005.02284.x

5. Dehner LP. Inflammatory myofibroblastic tumor. The continued definition of one type of so-called inflammatory pseudotumor. Am J Surg Pathol (2004) 28:1652-4. doi:10.1097/00000478-200412000-00016

6. Höhne S, Milzsch M, Adams J, Kunze C, Finke R. Inflammatory pseudotumor (IPT) and inflammatory myofibroblastic tumor (IMT): a representative literature review occasioned by a rare IMT of the transverse colon in a 9-years-old child. Tumori (2015) 101:249-56. doi:10.5301/tj.5000353

7. Gleason BC, Hornick JL. Inflammatory myofibroblastic tumours: where are we now? J Clin Pathol (2008) 61(4):428-37. doi:10.1136/jcp.2007.049387

8. Yu DC, Grabowski MJ, Kozakewich HP, Perez-Atayde AR, Voss SD, Shamberger RC, et al. Primary lung tumors in children and adolescents: a 90-year experience. J Pediatr Surg (2010) 45:1090-5. doi:10.1016/j.jpedsurg.2010.02.070

9. El-Desoky T, Nasef N, Osman E, Osman A, Zaki A, Zalata K. Endobronchial inflammatory pseudotumor: a rare cause of a pneumothorax in children. J Bronchology Interv Pulmonol (2013) 20:256-60. doi:10.1097/LBR.0b013e31829bccba

10. Johnson K, Notrica DM, Carpentieri D, Jaroszewski D, Henry MM. Successful treatment of recurrent pediatric inflammatory myofibroblastic tumor in a single patient with a novel chemotherapeutic regimen containing celecoxib. J Pediatr Hematol Oncol (2013) 35:414-6. doi:10.1097/MPH.0b013e3182915cef

11. Hammas N, Chbani L, Rami M, Boubbou M, Benmiloud S, Bouabdellah Y, et al. A rare tumor of the lung: inflammatory myofibroblastic tumor. Diagn Pathol (2012) 7:83. doi:10.1186/1746-1596-7-83

12. Prabhu SM, Choudhury SR, Solanki RS, Shetty GS. Multifocal intrathoracic inflammatory myofibroblastic tumour in children. Jpn J Radiol (2012) 30:453-7. doi:10.1007/s11604-012-0065-8

13. Brodlie M, Barwick SC, Wood KM, McKean MC, Welch A. Inflammatory myofibroblastic tumours of the respiratory tract: paediatric case series with varying clinical presentations. J Laryngol Otol (2011) 125:865-8. doi:10.1017/ S0022215111000648 cases in a national registry in order to improve knowledge of the disease and encode the best diagnostic and therapeutic approach.

\section{ETHICS STATEMENT}

The authors state that "written informed consent was obtained from the parents of the patient for the publication of this case report."

\section{AUTHOR CONTRIBUTIONS}

GR coordinated the writing group. FC and MG performed the literature review. All authors critically reviewed the manuscript, read, and approved the final version.

\section{FUNDING}

The authors state that no funding has been received.

14. Sacco O, Gambini C, Gardella C, Tomà P, Rossi UG, Jassoni V, et al. "Atypical steroid response" in a pulmonary: inflammatory myofibroblastic tumor. Pediatr Pulmonol (2010) 45:721-6. doi:10.1002/ppul.21237

15. Ochs K, Hoksch B, Frey U, Schmid RA. Inflammatory myofibroblastic tumour of the lung in a five-year-old girl. Interact Cardiovasc Thorac Surg (2010) 10:805-6. doi:10.1510/icvts.2009.219089

16. Fernández del Castillo Ascanio M, González CG, Pérez SP, Delgado LE. Inflammatory pseudotumor in a five-year-old girl. Radiologia (2013) 55:82-5. doi:10.1016/j.rx.2010.06.014

17. Lindemans CA, Bruinsma RA, Nikkels PG, Bröker FH, Arets HG. Pulmonary consolidation and inflammation: inflammatory pseudotumour in young children. Monaldi Arch Chest Dis (2009) 71:71-5.

18. Lizarbe MO, Olascoaga JH, García ER, Castiella TM, Sagaseta de Ilúrdoz Uranga María M, Garicano JM. Paediatric myofibroblastic tumours. A presentation of three cases. An Pediatr (Barc) (2009) 71:331-5. doi:10.1016/j. anpedi.2009.06.010

19. Breen DP, Dubus JC, Chetaille B, Payan MJ, Dutau H. A rare cause of an endobronchial tumour in children: the role of interventional bronchoscopy in the diagnosis and treatment of tumours while preserving anatomy and lung function. Respiration (2008) 76:444-8. doi:10.1159/000101718

20. Takayama Y, Yabuuchi H, Matsuo Y, Soeda H, Okafuji T, Kamitani T, et al. Computed tomographic and magnetic resonance features of inflammatory myofibroblastic tumor of the lung in children. Radiat Med (2008) 26:613-7. doi:10.1007/s11604-008-0284-1

21. Venizelos I, Papathomas T, Anagnostou E, Tsanakas J, Kirvassilis F, Kontzoglou G. Pediatric inflammatory myofibroblastic tumor of the trachea: a case report and review of the literature. Pediatr Pulmonol (2008) 43:831-5. doi:10.1002/ppul.20869

22. Sivanandan S, Lodha R, Agarwala S, Sharma M, Kabra SK. Inflammatory myofibroblastic tumor of the trachea. Pediatr Pulmonol (2007) 42:847-50. doi:10.1002/ppul.20651

23. Hoseok I, Joungho H, Ahn KM, Lee SI, Jhingook K. Complete surgical resection of inflammatory myofibroblastic tumor with carinal reconstruction in a 4-year-old boy. J Pediatr Surg (2005) 40:e23-5. doi:10.1016/j.jpedsurg. 2005.08.043

24. Pichler G, Eber E, Thalhammer G, Muntean W, Zach MS. Arthralgia and digital clubbing in a child: hypertrophic osteoarthropathy with inflammatory pseudotumour of the lung. Scand J Rheumatol (2004) 33:189-91. doi:10.1080/03009740310004702

25. Chan PW, Omar KZ, Ramanujam TM. Successful treatment of unresectable inflammatory pseudotumor of the lung with COX-2 inhibitor. Pediatr Pulmonol (2003) 36:167-9. doi:10.1002/ppul.10308

26. Prasad M, Thankachen R, Parihar B, Shukla V. Inflammatory pseudotumour of the lung. Interact Cardiovasc Thorac Surg (2004) 3:323-5. doi:10.1016/j. icvts.2003.11.018 
27. Panagiotopoulos N, Patrini D, Gvinianidze L, Woo WL, Borg E, Lawrence D. Inflammatory myofibroblastic tumour of the lung: a reactive lesion or a true neoplasm? J Thorac Dis (2015) 7:908-11. doi:10.3978/j.issn.2072-1439.2015. 04.60

28. Karnak I, Senocak ME, Ciftci AO, Cağlar M, Bingöl-Koloğlu M, Tanyel FC, et al. Inflammatory myofibroblastic tumor in children: diagnosis and treatment. J Pediatr Surg (2001) 36:908-12. doi:10.1053/jpsu.2001.23970

29. Choi BY, Kim WS, Cheon JE, Kim IO, Kim CJ, Yeon KM. Inflammatory myofibroblastic tumour of the liver in a child: CT and MR findings. Pediatr Radiol (2003) 33:30-3. doi:10.1007/s00247-002-0786-4

30. Athanassiadi K, Laenger F, Dickgreber N, Haverich A. Multiple inflammatory myofibroblastic tumors involving lung and mediastinum: a rare clinical entity. Thorac Cardiovasc Surg (2009) 57:343-6. doi:10.1055/s-0029-1185574

31. Oguz B, Ozcan HN, Omay B, Ozgen B, Haliloglu M. Imaging of childhood inflammatory myofibroblastic tumor. Pediatr Radiol (2015) 45:1672-81. doi:10.1007/s00247-015-3377-x

32. Alaggio R, Cecchetto G, Bisogno G, Gambini C, Calabrò ML, Inserra A, et al. Inflammatory myofibroblastic tumors in childhood: a report from the Italian Cooperative Group studies. Cancer (2010) 116:216-26. doi:10.1002/cncr.24684

33. Coffin CM, Patel A, Perkins S, Elenitoba-Johnson KS, Perlman E, Griffin CA. ALK1 and p80 expression and chromosomal rearrangements involving 2p23 in inflammatory myofibroblastic tumor. Mod Pathol (2001) 14:569-76. doi:10.1038/modpathol.3880352

34. Siminovich M, Galluzzo L, López J, Lubieniecki F, de Dávila MT. Inflammatory myofibroblastic tumor of the lung in children: anaplastic lymphoma kinase
(ALK) expression and clinico-pathological correlation. Pediatr Dev Pathol (2012) 15:179-86. doi:10.2350/11-10-1105-OA.1

35. Antonescu CR, Suurmeijer AJ, Zhang L, Sung YS, Jungbluth AA, Travis WD, et al. Molecular characterization of inflammatory myofibroblastic tumors with frequent ALK and ROS1 gene fusions and rare novel RET rearrangement. Am J Surg Pathol (2015) 39:957-67. doi:10.1097/PAS.0000000000000404

36. Messineo A, Mognato G, D’Amore ES, Antoniello L, Guglielmi M, Cecchetto G. Inflammatory pseudotumors of the lung in children: conservative or aggressive approach? Med Pediatr Oncol (1998) 31:100-4. doi:10.1002/(SICI) 1096-911X(199808)31:2<100::AID-MPO10>3.0.CO;2-R

37. Fabre D, Fadel E, Singhal S, de Montpreville V, Mussot S, Mercier O, et al. Complete resection of pulmonary inflammatory pseudotumors has excellent long-term prognosis. J Thorac Cardiovasc Surg (2009) 137:435-40. doi:10.1016/j.jtcvs.2008.07.009

Conflict of Interest Statement: The authors declare that the research was conducted in the absence of any commercial or financial relationships that could be construed as a potential conflict of interest.

Copyright (C) 2018 Camela, Gallucci, di Palmo, Cazzato, Lima, Ricci and Pession. This is an open-access article distributed under the terms of the Creative Commons Attribution License (CC BY). The use, distribution or reproduction in other forums is permitted, provided the original author(s) and the copyright owner are credited and that the original publication in this journal is cited, in accordance with accepted academic practice. No use, distribution or reproduction is permitted which does not comply with these terms. 